\title{
СОВРЕМЕННЫЕ КОНЦЕПЦИИ И ОСОБЕННОСТИ ПРОЯВАЕНИЯ САМОПОВРЕЖДАЮЩЕГО ПОВЕДЕНИЯ
}

\author{
С.В. Давидовский, С.А. Игумнов
}

ГУО «Белорусская медицинская академия последипломного образования», г. Минск, Беларусь ФГБУ «Национальный медицинский исследовательский центр психиатрии и наркологии им. В.П.Сербского» Минздрава России, г. Москва, Россия

\section{MODERN CONCEPTIONS AND MANIFESTATION FEATURES OF SELF-HARMING BEHAVIOR}

\author{
S. V. Davidouski, \\ S.A. Igumnov
}

Belarusian State Medical Academy for Postgraduate Education, Minsk, Belarus
National Research Center for Addictions - branch of National medical research center of psychiatry and narcology by name V.P. Serbsky, Moscow, Russia

Информация об авторах:

Давидовский Сергей Вмадимирович - кандидат медицинских наук (SPIN-код: 4314-6332; AuthorID: 884011). Место работы и должность: доцент кафедры психотерапии и медицинской психологии ГУО «Белорусская медицинская академия последипмомного образования". Адрес: Беларусь, 220013, г. Минск, ул. П. Бровки, 3. Телефон: + 375 (17) 340-18-19, экектронный адрес: davidouski@yandex.by

Игумнов Сергей А^ександрович - доктор медицинских наук, профеccop (Researcher ID: E-7975-2018; Scopus Author ID: 6602771038; ORCID iD: 0000-0002-0529-420X). Место работы и домжность: руководитель отдела клинической наркологии Национального научного центра наркологии - фимиал ФГБУ “Национальный медицинский исследовательский центр психиатрии и наркологии им. В.П. Сербского" Минздрава России. Адрес: Россия, 119002, г. Москва, Могимьцевский пер., 3. Телефон: +7 (495) 358-02-56; электронный адрес: sigumnov67@gmail.com

Information about the authors:

Davidouski Sergey Vladimirovich - MD, PhD (SPIN-code: 4314-6332; AuthorID: 884011). Place of work and position: Associate Professor of the Department of Psychotherapy and Medical Psychology of the State Educational Institution "Belarusian Medical Academy of Postgraduate Education". Address: Belarus, 220013, Minsk, 3 P. Brovki str. Phone: + 375 (17) 340-18-19, email address: davidouski@yandex.by

Igumnov Sergey Aleksandrovich - MD, PhD, Professor (Researcher ID: E-7975-2018; Scopus Author ID: 6602771038; ORCID iD: 0000-0002-0529-420X). Place of work and position: Head of the Department of Clinical Narcology of the National Research Centre for Addictions - branch of National medical research center of psychiatry and narcology by name V.P. Serbsky. Address: Russia, 119002, Moscow, 3 Mogiltsevsky lane. Phone: +7 (495) 358-02-56; email address: sigumnov67@gmail.com

В настоящее время выявлено несколько факторов биологического риска, обуславливающих суицидальное и самоповреждающее поведение. Различия касаются изменений в ключевых нейротрансмиттерных системах (серотонинергическая, полиаминовая стрессовая реакция, глутаматергическая и ГАМКергическая системы), воспалительной реакции, астроглиальной дисфункции, факторе нейрональной пластичности, что подтверждает необходимость дифференцировать из общего количества суицидальных попыток лиц, мотивированных к совершению суицида, и лиц, склонных к несуицидальному самоповреждающему поведению. Несуицидальное самоповреждающее поведение (англ.: non-suicidal self-injury - NSSI), - определяется как повторяющееся, преднамеренное, прямое повреждение тела без суицидальных намерений, которое не является социально приемлемым. Интегрированная теоретическая модель развития и поддержки NSSI предполагает, что этот вид поведения функционирует как метод регулирования эмоционального опыта и социального взаимодействия при возникновении стрессового события. В настоящее время NSSI включено в раздел 3 DSM-5 и отнесено к состояниям, рекомендованным для дальнейшего изучения. В американском диагностическом и статистическом руководстве по психическим расстройствам 4-го пересмотра (DSM-IV-TR) и МКБ-10 NSSI кодируется как симптом пограничного расстройства личности.

Ключевые слова: суицидальное и самоповреждающее поведение, самоповреждение, суицидальные намерения, пограничное расстройство личности (ПРЛ)

Несуицидальное самоповреждение (в английской транскрипции - non-suicidal self-injury - NSSI) определяется как повторяющееся, преднамеренное, прямое повреждение тела без суицидальных намерений, которое не является социально приемлемым $[1,2]$, и реали-
Non-suicidal self-injury (NSSI) is defined as repetitive, intentional, direct injury to the body without suicidal intent which is not socially acceptable $[1,2]$, and is implemented with the goal of reducing psychological discomfort. In the last decade, all over the world, 
зуются с целью уменьшить психологический дискомфорт. В последнее десятилетие во всём мире, в том числе и России, отмечается повышенный интерес к проблеме несуицидальных повреждений $[3,4]$.

Проявления NSSI чаще всего наступают в раннем подростковом возрасте, между 12 и 14 годами $[5,6]$. Большинство исследователей отмечают, что суицидальное поведение у детей до 13 лет - редкое явление [7], с 14-15-летнего возраста суицидальная активность резко возрастает, достигая максимума к 16-19 годам [5, 6, 8]. А.Г. Амбрумова, обследовав 770 детей, подростков и юношей с суицидальным поведением, установила, что в допубертатном возрасте (до 13 лет) попытку самоубийства совершали $14,4 \%$, в пубертатном (1316 лет) $-51,3 \%$, в постпубертатном (17-18 лет) - 33,8\% [8]. Главным отличительным признаком самоповреждающего поведения от суицидальной попытки является отсутствие осознанного намерения лишить себя жизни. Следует учитывать, что некоторые несуицидальные самоповреждающие действия, особенно в подростковом возрасте, могут приводить к смерти из-за неведения или неверного «расчёта дозы», с чем приходилось сталкиваться авторам статьи в своей клинической практике.

Необходимо также помнить о том, что эти две формы самоповреждений могут взаимно перекрываться: индивиды, совершающие суицидальные попытки, могут также демонстрировать несуицидальное самоповреждающее поведение, и наоборот. В реальной клинической ситуации наличие суицидальных намерений часто очень сложно оценить даже специалисту с большим опытом практической работы, что является серьёзным барьером в изучении данной проблемы. Поэтому, несмотря на то, что самоповреждающее поведение является широко распространённым явлением, данные о частоте NSSI значительно различаются по странам. На это влияют также особенности методологических подходов и, в частности, таких факторов, как тип поведения, классифицируемое как NSSI, а также метод оценки NSSI, демографические характеристики выборки и т.п. Высокие показатели распространённости отмечаются среди подростков, проходящих стационарное лечение, например, от $30 \%$ до $82,4 \%$ [9, 10], умеренно выраженную распространённость отмечают в общей популяции. В обзоре 53 исследований, опубликованных в период с 2005 по 2011 год по NSSI среди подростков, сообщалось о средней распространённости в течение жизни 18\% [11]. Среди студентов университетов этот процент составляет до $38,9 \%$ и $4-23 \%$ среди взрослых $[12,13,14,15]$. В настоящее время фигурируют следующие цифры распространённости: примерно $17,2 \%$ среди подростков, $13,4 \%$ среди молодых людей и студентов и $5,5 \%$ среди взрослых старше 25 лет. Эти данные согласуются с отдельным обзором о представленности NSSI среди подростков [11] и большим исследованием взрослых, отобранных случайным образом [16]. Считается, что NSSI значительно чаще встре- including Russia, there has been observed an increased interest to the problem of nonsuicidal injuries $[3,4]$.

The onset of NSSI most often occurs in early adolescence, between 12 and $14[5,6]$. Most researchers note that suicidal behavior in children under 13 years of age is a rare phenomenon [7], from the age of 14-15, suicidal activity sharply increases, reaching a maximum by the age of $16-19[5,6,8]$. A.G. Ambrumova, having examined 770 children, adolescents and young people with suicidal behavior, found that at the pre-pubertal age (up to 13 ) $14.4 \%$ of them committed suicide attempts, $51.3 \%$ attempted suicide during puberty (13-16), and $33.8 \%$ did so in the postpubertal (17-18) [8]. The main distinguishing feature of self-harming behavior from a suicidal attempt is the lack of a conscious intention to take one's own life. It should be borne in mind that some non-suicidal self-injurious actions, especially during adolescence, can lead to death due to ignorance or incorrect "dose calculation", which the authors of the article had to face in their clinical practice.

It should also be remembered that these two forms of self-harm can overlap: individuals who commit suicide may also exhibit nonsuicidal self-harming behavior and vice versa. In a real clinical situation, the presence of suicidal intentions is often very difficult to assess even for a specialist with extensive practical experience, which is a serious barrier to studying this problem. Therefore, while self-injurious behavior is widespread, the frequency of NSSI data varies considerably across countries. This is also influenced by the peculiarities of methodological approaches and, in particular, such factors as the type of behavior classified as NSSI, as well as the method of assessing NSSI, demographic characteristics of the sample, etc. High prevalence rates are noted among adolescents undergoing inpatient treatment, for example, from $30 \%$ to $82.4 \%$ [9, 10], while for general population moderately pronounced prevalence is recorded. A review of 53 studies published between 2005 and 2011 on adolescent NSSI reported an average lifetime prevalence of $18 \%$ [11]. This percentage can be as high as $38.9 \%$ among university students and range 4-23\% among adults $[12,13,14,15]$. Currently, the following prevalence figures are accepted: approximately $17.2 \%$ for adolescents, $13.4 \%$ for young people and students, and 5.5\% for adults over 25 . These findings are consistent with a separate review of the prevalence of NSSI among adolescents [11] and a large study of randomly selected adults [16]. It is believed that NSSI is significantly more 
чается у женщин, чем у мужчин. Так согласно данным по Минской области за 2015-2019 годы среди детей и подростков девочки составляли $85 \%$ от общего количества случаев самоповреждения.

Смертность от суицидов в возрасте от 15-29 лет составляет $8,5 \%$ всех смертей, являясь второй по значимости причиной смертности после дорожнотранспортных происшествий в мире [17]. Следует отметить, что подростковый возраст и период ранней взрослости (20-29 лет) характеризуется драматическими изменениями в организме и характеризуется повышенной возбудимостью, резкой сменой настроения и переживаний, что и обуславливает повышенную реактивность естественной стресс-реакции подростка на социальные стимулы, создавая тем самым уникально уязвимые временные рамки для проявления суицидального поведения. В этот период происходят изменения в нейронных сетях головного мозга, что позволяет проводить более сложные социальные сравнения и получать более устойчивый смысл самооценки, которая в значительной степени зависит от воспринимаемых оценок со стороны сверстников $[18,19]$. Исследования в области нейробиологии развития показывают, что подростки в период пубертата продуцируют более дифференцированные реакции на стимулы внешней среды, что позволяет им на основании получаемого социального опыта формировать свою самооценку, но при этом зрелые способности регулировать свои эмоции или подавлять импульсивные реакции отсутствуют [20]. Развитие предметных чувств ещё не произошло, что не позволяет им сформировать устойчивые эмоциональные отношения с ближайшим окружением. Повышенная реактивность, обусловленная подростковым возрастом, повышает интенсивность физиологических ответов на стрессоры [21] и префронтальную активацию мозга во время социальной оценки [20] и, таким образом, увеличивает трудности, связанные с оценкой социальных событий [21]. По-видимому, это и является причиной сбоев в биологических реакциях на острый стресс, что может лежать в основе острых суицидальных кризисов у подростков, сопровождающихся самоповреждающим поведением.

Формы NSSI включают такие виды поведения, как самопорезы, умышленно наносимые ожоги, царапины, удары и др. $[6,16,22]$. В настоящее время считается, что большинство людей, совершающих NSSI, используют более одного метода и зоны, с травматическими воздействиями на руки, ноги, запястья и живот $[15,17]$. Наиболее распространённым методом считается самоповреждения острыми предметами (более 70\%), за которым следуют удары головой, царапины, удары и ожоги $[22,23,24]$. Согласно данным по г. Минску за 2007-2014 годы, среди методов самоповреждения преобладали такие методы как самоотравления и самоповреждения (не менее $60 \%$ от всех случаев самоповреждения, преимущественно в возрасте 20-39 лет) common type of behavior for women rather than men. For example, according to the 2015-2019 children and adolescents data for Minsk region female gender accounted for $85 \%$ of the total number of cases of self-harm.

Suicide mortality at the age of 15-29 years constitutes $8.5 \%$ of all deaths, being the second leading cause of death after road traffic accidents in the world [17]. It should be noted that adolescence and early adulthood (20-29 years old) are characterized by dramatic changes in the body and are characterized by increased excitability, sharp mood and experiences changes, which determines the increased reactivity of the adolescent's natural stress response to social incentives, thereby creating a uniquely vulnerable time frame for suicidal behavior. During this period, changes occur in the neural networks of the brain, which allows for more complex social comparisons and obtaining a more stable sense of self-esteem, which largely depends on the perceived assessments from peers [18, 19]. Research in the developmental neurobiology field shows that adolescents during puberty produce more differentiated responses to environmental stimuli, which allows them to form their self-esteem based on the received social experience, but at the same time they do not possess mature abilities to regulate their emotions or suppress impulsive responses. [20]. The development of objective feelings has not yet occurred, which does not allow them to form stable emotional relationships with the immediate environment. Increased reactivity associated with adolescence increases the intensity of physiological responses to stressors [21] and prefrontal brain activation during social assessment [20] and thus increases the difficulties associated with assessing social events [21]. Apparently, this is the reason for disruptions in biological responses to acute stress, which may underlie acute suicidal crises in adolescents, accompanied with selfdamaging behavior.

Forms of NSSI include such types of behavior as self-cuts, deliberately inflicted burns, scratches, blows, etc. [6, 16, 22]. It is now believed that most people performing NSSI use more than one method and body area inflicting traumatic effects on the arms, legs, wrists and abdomen $[15,17]$. The most common method is considered to be selfcutting with sharp objects (over 70\%), followed by head blows, scratches, blows and burns [22, 23, 24]. According to the data for the city of Minsk for 2007-2014, among the methods of self-harm, such methods as selfpoisoning and self-cutting prevailed (at least $60 \%$ of all cases of self-harm, mainly at the 
[25]. Согласно данным по Минской области за 20152019 годы отмечались следующие методы самоповреждения: нанесение самоповреждений - $44,5 \%$, отравление $-38,5 \%$, повешение - $11,4 \%$, падение с высоты $3 \%$, утопление $-0,4 \%, 2,2 \%$ составили редко используемые способы (огнестрельное ранение, падение под поезд, самосожжение и др.).

NSSI является распространённым явлением среди подростков и взрослых, связанным со значительными психическими нарушениями, включая посттравматическое стрессовое расстройство [26], депрессивные расстройства [27], обсессивно-компульсивное расстройство [26], тревожное расстройство [27], пограничное расстройство личности (ПЛР) $[2,28]$ и расстройство пищевого поведения [29].

Одни из самых ранних попыток определить данный синдром были сделаны ещё в 60-х годах XX столетия H. Graff и R. Mallin, но из-за включения попыток самоубийства в определения суицидального поведения они потерпели неудачу [30, 31, 32]. В 1984 году J.Kahan и E.M. Pattison [33] дифференцировали поведение, связанное с самоубийством, от самоубийства и предложили отдельное диагностическое расстройство - синдром преднамеренного самоповреждения. Позже A.R. Favazza и R.J. Rosenthal [34] предположили, что привычное и повторяющееся самоповреждающее поведение можно рассматривать как расстройство импульсного контроля. В начале 2000-х J.J. Muehlenkamp предложил рассматривать NSSI как отдельное диагностическое расстройство [35]. В дальнейшем P. Wilkinson и I. Goodyer [36] посчитали, что предоставление NSSI собственной диагностической категории улучшит качество диагностики и увеличит количество исследований по этиологии, её лечению и результату.

Учитывая высокую распространённость самоповреждающего поведения среди клинических выборок и в общей популяции подростков [2, 4, 7], рабочая группа по расстройствам настроения при подготовке диагностического и статистического руководства по психическим расстройствам DSM-5 предложила включить NSSI как отдельную диагностическую рубрику [37]. Критерии данного расстройства подвергались неоднократным пересмотрам, из-за неполного набора предложенных критериев неадекватных размеров исследовательских выборок и межкритериальной надёжности [38].

В настоящее время NSSI включено в раздел 3 DSM-5 и отнесено к состояниям, рекомендованным для дальнейшего изучения, при этом должны быть соблюдены следующие критерии:

А. За прошедший год индивид, по крайней мере, 5 дней преднамеренно наносил себе телесные повреждения, не пытаясь совершить суицид.

В. Индивид совершает самоповреждающие действия по одной или нескольким из следующих причин: наносит самоповреждения, ожидая получить облегчение от негативных эмоций; чтобы разрешить внутри- age of 20-39 years) [25]. According to the data for the Minsk region for 2015-2019, the following self-harm methods were noted: selfcutting $-44.5 \%$, poisoning $-38.5 \%$, hanging $-11.4 \%$, falling from a height $-3 \%$, drowning $-0,4 \%$, rarely used methods (gunshot wound, falling under a train, self-immolation, etc.) made up $2.2 \%$.

NSSI is a common phenomenon among adolescents and adults associated with significant mental disorders, including posttraumatic stress disorder [26], depressive disorders [27], obsessive-compulsive disorder [26], anxiety disorder [27], borderline personality disorder (BPD) $[2,28]$ and eating disorder [29].

Some of the earliest attempts to define this syndrome date back to the 60 s of the XX century by N. Graff and R. Mallin, but since suicide attempts were then included in the definition of suicidal behavior, they failed [30, 31, 32]. In 1984 J. Kahan and E.M. Pattison [33] differentiated suicide associated behavior from suicide itself and proposed a separate diagnostic disorder - deliberate self-harm syndrome. Later A.R. Favazza and R.J. Rosenthal [34] suggested that habitual and repetitive self-injurious behavior can be considered an impulse control disorder. In the early 2000s, J.J. Muehlenkamp proposed to consider NSSI as a separate diagnostic disorder [35]. Subsequently, P. Wilkinson and I. Goodyer [36] considered that providing NSSI with its own diagnostic category would improve the quality of diagnosis and increase the number of studies on etiology, its treatment and outcome.

Given the high prevalence of selfinjurious behavior among clinical samples and in the general adolescent population [2, 4, 7], the Mood Disorders Working Group, in the preparation of the DSM-5 Diagnostic and Statistical Manual for Mental Disorders, proposed including NSSI as a separate diagnostic heading [37]. The criteria for this disorder have undergone repeated revisions, due to the incomplete set of proposed criteria for inadequate research sample sizes and intercriteria reliability [38].

The NSSI is currently included in section 3 of the DSM-5 and is classified as a recommended condition for further study with the following criteria obligatory to be met:

A. Over the past year, the individual has intentionally inflicted bodily harm on himself for at least 5 days without attempting to commit suicide.

B. The individual commits self-harming acts for one or more of the following reasons: self-injury with the expectation to receive 
личностностный конфликт; пытается достичь положительного эмоционального состояния.

С. Предварять самоповреждающий акт должны (и/или): негативные мысли или чувства (C1a), конфликты с другими людьми $(\mathrm{Clb})$, озабоченность поведением, которое трудно контролировать (С2), повторяющиеся мысли о самоповреждающем поведении (С3).

D. Совершённый акт является социально неприемлемым.

Е. Самоповреждающее поведение или его последствия вызывают клинически значимый деструктивный стресс.

F. Действие не связано с психотическим эпизодом, делирием, опьянением или абстинентным синдромом, и не может быть причиной другого заболевания.

Дополнительно выделяются 2 подтипа неуточнённого NSSI:

Тип 1 (sub-threshold / «подпороговые»): относятся случаи с меньшей чем 5 раз за последний год частотой самоповреждений;

Тип 2 (intent uncertain / «неясные намерения»): случаи, когда при нанесении самоповреждений наравне с желанием избавиться от неприятных чувств или решить межличностные трудности имело место желание совершить суицид.

В ранее принятых классификационных системах (DSM-IV-TR и МКБ-10) расстройство NSSI кодируется как симптом ПЛР. Все виды аутоагрессивного поведения в МКБ-10 кодируются в зависимости от характера повреждений в рубриках X и Ү. При этом в руководстве указано, что «данный класс, который в предыдущих пересмотрах МКБ являлся дополнительным, позволяет классифицировать происшествия, условия и обстоятельства в качестве причины травмы, отравления и другого неблагоприятного воздействия. В тех случаях, когда используется код из данного класса, подразумевается, что он должен применяться как дополнение к коду из другого класса, указывающему на характер состояния».

NSSI может встречаться у лиц, которые не получают диагноз ПРЛ, и не каждый человек, который получает диагноз ПРЛ, демонстрирует поведение, связанное с самоповреждением [39]. Различия между NSSIгруппой и группой ПЛР предполагают определять NSSI как синдром сам по себе [40, 41]. Введение расстройства NSSI признает важность дифференциации NSSI от попытки самоубийства. Хотя и попытки самоубийства, и NSSI соответствуют поведению, наносящему себе вред, существуют важные клинические различия между данными формами поведения как в этиологии, так и по выполняемым функциям и методам. Исследования расстройства NSSI, проведённые Американской психиатрической ассоциацией, показало высокий процент тех, кто получил телесные повреждения и соответствовал критериям, предложенным DSM-5 [42, 43]. В комбинированных выборках пациентов стационарного и интен- relief from negative emotions; to resolve intrapersonal conflict; an attempt to reach positive emotional state.

C. The self-injurious act should be preceded by (and/or): negative thoughts or feelings (C1a), conflicts with other people (C1b), preoccupation with behavior that is difficult to control (C2), repetitive thoughts about selfinjurious behavior (C3).

D. The act committed is socially unacceptable.

E. Self-injurious behavior or its consequences cause clinically significant destructive stress.

F. The action is not associated with a psychotic episode, delirium, drunkenness or withdrawal symptoms, and cannot be the cause of another illness.

Additionally, there are 2 subtypes of unspecified NSSI identified:

Type 1 (sub-threshold): cases of selfharm with a frequency less than 5 times in the past year;

Type 2 (intent uncertain): cases when inflicting self-harm, along with the desire to get rid of unpleasant feelings or resolve interpersonal difficulties, there was a desire to commit suicide.

In earlier classification systems (DSMIV-TR and ICD-10), NSSI disorder is coded as a symptom of BPD. All types of autoaggressive behavior in ICD-10 are coded un$\operatorname{der} \mathrm{X}$ and $\mathrm{Y}$ headings depending on the nature of injuries. At the same time, the manual states that "this class that was additional in previous revisions of the ICD, allows us to classify incidents, conditions and circumstances as the cause of injury, poisoning and other adverse effects. In cases where a code from this class is used, it is understood that it should be used in addition to the code from another class that indicates the nature of the state".

NSSI can be performed by individuals who are not diagnosed with BPD, and not every person who is diagnosed with BPD would inflict self-harming behavior [39]. The differences between the NSSI group and the BPD group suggest defining NSSI as a syndrome in itself [40, 41]. The introduction of the NSSI disorder recognizes the importance of differentiating NSSI from attempted suicide. While both the attempted suicide and the NSSI are consistent with self-harming behaviors, there are important clinical differences between these behaviors, both in etiology and in function and method. NSSI studies by the American Psychiatric Association found a high percentage of those who were injured and met the criteria proposed by the DSM- 5 
сивного амбулаторного лечения $85,5 \%$ соответствовали критерию А [43]. При оценке критерия В высокая степень одобрения была обнаружена в клинической выборке подростков и взрослых [39, 43, 44], а также в общих выборках для взрослых $[39,45]$.

Исследования психологических причин, лежащих в основе поведения NSSI, на немецкой выборке показало, что 56,8\% немецкой выборки стационарных больных использовало NSSI «для прекращения плохих чувств» [46]. Согласно данным Б. Алмазова (1981) [цит. по 47], который обследовал группу подростков в возрасте 14-18 лет, умышленно нанесших себе порезы, установлено, что только 4\% из обследованных в момент самоповреждения имели суицидальные мысли, $30 \%$ совершили самоповреждения как результат ссоры со сверстниками, у $20 \%$ как обряд «братанья кровью» и $20 \%$ как демонстрация, бравада перед сверстниками.

В настоящее время считается, что NSSI является преходящим явлением. Так крупное продольное исследование показало снижение данного типа поведения в молодом возрасте [48]. Интегрированная теоретическая модель развития и поддержки NSSI [2] предполагает, что этот вид поведения функционирует как метод регулирования как эмоционального опыта, так и социальных ситуаций при возникновении стрессового события. Эта модель была введена M.K. Nock и M.J. Prinstein (2004), известна как четырехфакторная модель - в английской транскрипции The Four Factor Model (FFM) [49]. Модель FFM основана на поведенческой теории, которая фокусируется на предшествующем и последующем влиянии на поведение. FFM разграничивает два дихотомических измерения функциональных процессов: непредвиденные обстоятельства межличностного / социального и внутриличностного / автоматического и усиление положительного против отрицательного. Четыре процесса, предложенные моделью, включают в себя: автоматическое отрицательное подкрепление, когда NSSI служит для уменьшения отрицательных внутренних состояний, автоматическое положительное подкрепление, когда NSSI служит для генерирования положительных чувств, социальное отрицательное подкрепление, когда NSSI служит для того, чтобы избежать межличностных потребностей, и социальное положительное подкрепление, когда NSSI служит для привлечения внимания или увеличения социальной поддержки [2].

Функция «самонаказания», как правило, отмечалась подростками и взрослыми среди клинических выборок $[46,50,51]$. Для взрослых функция NSSI в большей степени состоит в уменьшения отрицательных эмоций и переживаний, чем для получения социальной поддержки [15]. Можно сказать, что у взрослых самоповреждающее поведение нередко выполняет функцию «восстановления нормального эмоционального состояния» и предоставляет возможность отвлечься от кризисной ситуации.

В настоящее время отмечена также различная
$[42,43]$. In the combined samples of inpatients and intensive outpatients, $85.5 \%$ met criterion A [43]. When evaluating criterion B, a high degree of approval was found in a clinical sample of adolescents and adults [39, 43, 44], as well as in general samples for adults $[39,45]$.

Studies of the psychological causes underlying NSSI behavior in a German sample showed that $56.8 \%$ of a German inpatient sample resorted to NSSI "to cease bad feelings" [46]. According to B. Almazov (1981) [cit. according to 47], which examined a group of adolescents aged 14-18 years who intentionally inflicted cuts on themselves, it was found that only $4 \%$ of those examined at the time of self-harm had suicidal thoughts, $30 \%$ committed self-harm as a result of quarrels with peers, $20 \%$ did that as a rite of "blood brotherhood" and 20\% as a demonstration, bravado in front of peers.

NSSI is now considered to be a transitory phenomenon. Thus, a large long-term study showed a decrease in this type of behavior at a young age [48]. The integrated theoretical model of development and support NSSI [2] suggests that this type of behavior functions as a method of regulating both emotional experience and social situations when a stressful event occurs. This model was introduced by M.K. Nock and M.J. Prinstein (2004), known as the Four Factor Model (FFM) [49]. The FFM model is based on behavioral theory that focuses on the antecedent and subsequent influences on behavior. FFM distinguishes between two dichotomic dimensions of functional processes: interpersonal/social contingencies and intrapersonal/automatic contingencies, and positive versus negative amplification. The four processes suggested by the model include: automatic negative reinforcement, where NSSI serves to reduce negative internal states, automatic positive reinforcement, where NSSI serves to generate positive feelings, social negative reinforcement, where NSSI serves to avoid interpersonal needs, and socially positive reinforcement, where the NSSI serves to gain attention or increase social support [2].

As a rule, the "self-punishment" function was noted by adolescents and adults among clinical samples [46, 50, 51]. For adults, the function of NSSI is to a greater extent to reduce negative emotions and experiences rather than to receive social support [15]. We can say that in adults, self-harming behavior often performs the function of "restoring a normal emotional state" and provides an opportunity to escape from a crisis situation.

Currently, there are also different brain 
морфология мозга и нейронная активность у пациентов c NSSI или с ПЛР по сравнению со здоровым контролем, что может быть обусловлено различным восприятием эмоциональной и физической боли. Нейробиологическая модель NSSI [52] предполагает, что аномалии в серотонинергической, допаминергической и опиоидной системах, а также в гипоталамо-гипофизарнонадпочечниковой (далее - ГГН) оси приводят к повышенному уровню восприимчивости к стрессу. Поэтому в случае стресса использование NSSI можно трактовать, как метод восстановления измененного опиоидного гомеостаза. Результаты исследований магнитнорезонансной терапии указывают на гипервозбуждение лимбических структур (таких как миндалина) [53]. Активация этих структур уменьшается как после индукции болевых раздражителей [54], так и после воображения акта NSSI [54]. Это и обуславливает предположение, что NSSI служит для регулирования стресса в сильно активированной лимбической системе.

Что касается уровня нейротрансмиттеров, то существует достаточно доказательств связи между импульсивным поведением и недостатком серотонина. Однако NSSI часто не может быть описан как преимущественно импульсивное поведение $[55,56]$. В настоящее время существует мало доказательств в пользу поддерживающего механизма дефицита серотонина в формировании NSSI [51] в отличие от установленной связи между серотонинергической дисфункцией и повышенным риском насильственной суицидальной попытки $[57,58]$, что подтвердило и исследование, проводимое в рамках Государственной программы научных исследований «Фундаментальные и прикладные науки - медицине», которое выявило статистически значимые различия между группами с насильственными и ненасильственными методами самоповреждения по встречаемости генотипа HTR1 [59].

То же самое относится и к вовлечению дофаминергической нейротрансмиссии у людей с NSSI. B проводимых исследованиях [51] не было обнаружено различий в уровнях метаболитов серотонина или дофамина в спинномозговой жидкости у пациентов с NSSI. Результаты исследований по кортизолу и ГГН оси у людей и животных с NSSI показали изменённый ответ кортизола $[60,61]$. Исследователями также отмечен факт изменения уровня эндогенных опиоидов, что возможно, объясняет аддиктивное качество NSSI, которое было описано у людей с тяжёлым NSSI [62]. Эти эндогенные опиоиды могут служить объяснением явления гипоалгезии или анальгезии у пациентов с повторяющимся NSSI, которое, по-видимому, обратимо после прекращения NSSI [63]. Интересно отметить, что в недавнем метаанализе [64] подростковое самоубийство было описано как сбой систем, вовлечённых в острые реакции на стресс: вегетативная нервная система, ось ГГН, воспалительный ответ, что подтверждает интегрированную теоретическую модель NSSI, предложен- morphologies and neuronal activity in patients with NSSI or BPD compared to healthy controls, which can be caused by different perceptions of emotional and physical pain. The NSSI neurobiological model [52] suggests that abnormalities in the serotonergic, dopaminergic and opioid systems, as well as in the hypothalamic - pituitary - adrenal (hereinafter HPA) axis, lead to an increased level of susceptibility to stress. Therefore, in the case of stress, using NSSI can be interpreted as a method for restoring altered opioid homeostasis. Results from studies of magnetic resonance therapy indicate hyperexcitation of limbic structures (such as the amygdala) [53]. The activation of these structures decreases both after the induction of pain stimuli [54] and after imagining a NSSI act [54]. This leads to the assumption that NSSI serves to regulate stress in a highly activated limbic system.

In terms of neurotransmitter levels, there is ample evidence of a link between impulsive behavior and a lack of serotonin. However, NSSI often cannot be described as predominantly impulsive behavior [55, 56]. Currently, there is little evidence to confirm the role of serotonin deficiency in the formation of NSSI [51], unlike the already established association between serotonergic dysfunction and an increased risk of suicide attempt $[57,58]$ verified by the study conducted within the framework of State program of scientific research "Fundamental and applied sciences - to medicine" that revealed statistically significant differences between groups with violent and non-violent methods of self-harm in the occurrence of the HTR1 genotype [59].

The same is true for the involvement of dopaminergic neurotransmission in people with NSSI. In ongoing studies [51], no differences were found in the levels of serotonin or dopamine metabolites in cerebrospinal fluid in patients with NSSI. The results of studies on cortisol and HPA axis in humans and animals with NSSI showed an altered cortisol response $[60,61]$. The researchers also noted the fact that the level of endogenous opioids changed, which may explain the addictive quality of NSSI, which was described in people with severe NSSI [62]. These endogenous opioids may explain the phenomenon of hypoalgesia or analgesia in patients with recurrent NSSI, which appears to be reversible after discontinuation of NSSI [63]. It is interesting to note that in a recent meta-analysis [64], adolescent suicide was described as a failure of systems involved in acute reactions to stress: autonomic nervous system, HPA axis, inflammatory response, which confirms the integrated theo- 
ную M.K. Nock (2010).

Проведённое в рамках научно-исследовательской работы - «Изучить молекулярно-генетические предикторы суицидального поведения с целью разработки диагностических критериев повышенного риска суицида» (Государственной программы научных исследований «Фундаментальные и прикладные науки - медицине», госрегистрация № 20161106 от 11.06.2016 г., Республика Беларусь, при научно-методическом содействии Национального медицинского исследовательского центра психиатрии и наркологии им. В.П. Сербского Минздрава России) - также выявило наличие социально-психологических, биохимических и генетических факторов, позволяющих разграничивать различные формы самоповреждающего поведения в зависимости от выраженности мотивации к совершению суицида, что изложено в ряде научных статей $[58,65]$. В результате проводимого исследования было отмечено, что в группе лиц с самоповреждающим поведением наблюдалось повышение уровня содержания кортикотропного рилизинг фактора (далее - КТРГ) и снижение адренокортикотропного гормона (далее - АКТГ) и кортизола по сравнению с контролем в отличие от лиц, с выраженной мотивацией к совершению суицида. В данной группе, наоборот, отмечалось снижение уровня КРТГ и одновременное повышение АКТГ и кортизола, что свидетельствовало о дезорганизации работы ГГН оси. Частота встречаемости аллеля С гена HTR1A у мужчин группы лиц, мотивированных к совершению суицида, была достоверно выше, чем частота встречаемости данного аллеля у лиц мужского пола, совершивших различного типа несуицидальные самоповреждения $(\mathrm{p}=0,04)$.

В настоящее время выявлено несколько факторов биологического риска, обуславливающих суицидальное и самоповреждающее поведение: изменения в ключевых нейротрансмиттерных системах (серотонинергическая, полиаминовая стрессовая реакция, глутаматергическая и ГАМКергическая системы), воспалительной реакции, астроглиальной дисфункции, фактора нейрональной пластичности, содержания липопротеиновых фракций в периферической крови $[66,67]$, что подтверждает необходимость выделять из общего количества суицидальных попыток лиц, мотивированных к совершению суицида, соотношения которых согласно данным ВОЗ составляет $1: 20$ [17].

На сегодняшний день дополнительно предложено три диагноза, описывающих суицидальное поведение:

- Суицидальное расстройство поведения (в английской транскрипции - Suicidal Behavior Disorder SBD) [68], сфокусированное на попытке самоубийства в течение последних двух лет. Данное расстройство включено в раздел 3 и требует дальнейшего изучения [38], так же, как и NSSI.

- Синдром суицидального кризиса (в английской транскрипции - Suicide Crisis Syndrome - SCS) [69] и

- Острое суицидальное аффективное расстройство retical model of NSSI proposed by M.K. Nock (2010).

Our research conducted within the framework of research work - "To study molecular genetic predictors of suicidal behavior in order to develop diagnostic criteria for an increased risk of suicide" (State program of scientific research "Fundamental and applied sciences - to medicine", state registration No. 20161106 dated 06/11/2016 city, Republic of Belarus, with the scientific and methodological assistance of the National Medical Research Center for Psychiatry and Narcology after V.P. Serbsky of the Ministry of Health of Russia) - also revealed the presence of sociopsychological, biochemical and genetic factors that make it possible to distinguish between various forms of self-injurious behavior depending on the severity of motivation to commit suicide, which is described in a number of scientific articles [58,65]. As a result of the study, it was noted that in the group of persons with self-injurious behavior, there was an increase in the level of corticotropic releasing factor (hereinafter referred to as CTRF) and a decrease in adrenocorticotropic hormone (hereinafter referred to as ACTH) and cortisol compared with control, in contrast to individuals, with pronounced motivation to commit suicide. In this group, on the contrary, there was a decrease in the CTRF level and a simultaneous increase in ACTH and cortisol, which indicated the disorganization of the HPA axis. The frequency of occurrence of the $\mathrm{C}$ allele of the HTR1A gene in males among persons motivated to commit suicide was significantly higher than the frequency of occurrence of this allele in males who committed various types of non-suicidal self-harm $(\mathrm{p}=0.04)$.

Currently, several biological risk factors have been identified that cause suicidal and self-harming behavior: changes in key neurotransmitter systems (serotonergic, polyamine stress response, glutamatergic and GABAergic systems), inflammatory response, astroglial dysfunction, neuroplasticity factor, content of lipoprotein fractions in peripheral blood [66, 67], which confirms the need to distinguish those motivated to commit suicide from the total number of suicidal attempters, the ratio of whom according to the WHO is 1 : 20 [17].

To date, three additional diagnoses have been proposed that describe suicidal behavior:

- Suicidal Behavior Disorder (SBD) [68] focused on attempted suicide over the past two years. This disorder is included in section 3 and requires further study [38], as well as NSSI. 
(в английской транскрипции - Acute Suicidal Affective Disturbance - ASAD) [70], которые описывают острое предсуицидальное психическое состояние и отсутствуют в DSM-5, так как концепция данных расстройств была описана значительно позже.

Два нижеперечисленных синдрома симптоматически перекрываются, но также весьма различаются тем, что SCS не включает суицидальные мысли, в то время как ASAD основан на быстро нарастающей суицидальной активности [70, 71]. Все это указывает на формирование в настоящее время новых концепций и представлений о суицидальном или самоповреждающем поведении, что в будущем позволит более дифференцированно подходить к описанию данного сложного явления, выявляя значимые триггеры для формирования мотивации к совершению суицида и признаки, характерные для несуицидального самоповреждающего поведения.

Выводы. Таким образом, разработка новых диагностических критериев позволяет внести ясность в понимание особенностей самоповреждающего поведения и поможет эффективно идентифицировать лиц, подверженных суицидальному риску.

\section{Литература / References:}

1. Favazza A.R. Bodies under siege: self-mutilation and body modification in culture and psychiatry, $2^{\text {nd }}$ Ed. Baltimore, MD. John Hopkins University Press, 1996.

2. Nock M.K. Self-injury. Annu. Rev. Clin. Psychol. 2010; 6: 339363. DOI: 10.1146/annurev.clinpsy.121208.131258

3. Зинчук М.С., Аведисова А.С., Гехт А.Б. Несуицидальное самоповреждающее поведение при психических расстройствах непсихотического уровня: эпидемиология, социальные и клинические факторы риска. Журнал неврологии и психиатрии им. С.С. Корсакова. 2019; 119 (3): 108-119. [Zinchuk M.S., Avedisova A.S., Guekht A.B. Nonsuicidal self-injury behavior in non-psychotic disorders: epidemiology, social and clinical risk factors. Korsakov journal of neurology and psychiatry. 2019; 119 (3): 108-119.] (In Russ)

4. Евсеев В.Д., Пешковская А.Г., Мацута В.В., Мандель А.И. Несуицидальные самоповреждения (NSSI) и их связь с цифровыми данными социальной сети. Академический журнал $3 a$ падной Сибири. 2020; 16 (3): 38-41. [Evseev V. D., Peshkovskaya A. G., Matsuta V. V., Mandel A. I. non-Suicidal self-harm (NSSI) and their relation to digital data of the social network. Academic Journal of West Siberia. 2020; 16 (3): 38-41.] (In Russ)

5. Nock M.K., Joiner T.E., Gordon K.H., Lloyd-Richardson E., Prinstein M.J. Nonsuicidal self-injury among adolescents: diagnostic correlates and relation to suicide attempts. Psychiatry Res. 2006; 144: 65-72. DOI: 10.1016/j.psychres.2006.05.010

6. Muehlenkamp J.J., Gutierrez P.M. Risk for suicide attempts among adolescents who engage in non-suicidal self-injury. Arch. Suicide Res. 2007; 11: 69-82. DOI: 10.1080/13811110600992902

7. Barrocas A.L., Hankin B.L., Young J.L., Abela J.R. Rates of nonsuicidal self-injury in youth: age, sex, and behavioural methods in a community sample. Pediatrics. 2012; 130: 39-45. DOI: 10.1542/peds.2011-2094

8. Амбрумова А. Г. Методические рекомендации по профилактике суицидальных действий в детском и подростковом возрасте. M., 1978. [Ambrumova A.G. Methodical recommendations for the prevention of suicidal actions in childhood and adolescence. M., 1978.] (In Russ)

9. DiClemente R.J., Ponton L.E., Hartley D. Prevalence and correlates of cutting behavior: risk for HIV transmission. J. Am. Acad. Child Adolesc. Psychiatry. 1991; 30: 735-739. DOI: 10.1016/S0890-8567(10)80007-3
- Suicide Crisis Syndrome (SCS) [69]
and
- Acute Suicidal Affective Disturbance (ASAD) [70], which describe an acute presuicidal mental state and are absent from DSM-5, since the concept of these disorders was described much later.

The two syndromes listed above overlap symptomatically, but are also quite different in that SCS does not include suicidal thoughts, while ASAD is based on rapidly increasing suicidal activity [70, 71]. All this indicates the formation of new concepts and ideas about suicidal or self-injurious behavior at present, which in the future will allow a more differentiated approach to the description of this complex phenomenon, identifying significant triggers for the formation of motivation to commit suicide and signs characteristic of nonsuicidal self-injurious behavior.

Conclusions.

Thus, the development of new diagnostic criteria makes it possible to clarify the understanding of the characteristics of self-harming behavior and will help to effectively identify persons at risk of suicide.

10. Nock M.K., Prinstein M.J. A functional approach to the assessment of self-mutilative behavior. J. Clin. Consult. Psychol. 2004; 72: 885-890. DOI: 10.1037/0022-006X.72.5.885

11. Muehlenkamp J.J., Claes L., Havertape L., Plener P.L. International prevalence of adolescent non-suicidal self-injury and deliberate self-harm. Child Adolesc. Psychiatry Ment. Health. 2012; 6: 1-9. DOI: 10.1186/1753-2000-6-10

12. Gratz K.L. Conrad S.D., Roemer L. Risk factors for deliberate self-harm among college students. Am. J. Orthopsychiatry. 2002; 1: 128-140. DOI: 10.1037/0002-9432.72.1.128

13. Whitlock J., Eckenrode J., Silverman D. Self-injurious behaviors in a college population. Pediatrics. 2006; 117: 1939-1948. DOI: 10.1542/peds.2005-2543

14. Plener P.L., Libal G., Keller F., Fegert J.M., Muehlenkamp J.J. An international comparison of non-suicidal self-injury (NSSI) and suicide attempts: Germany and the USA. Psychol. Med. 2009; 39: 1549-1558. DOI: 10.1017/S0033291708005114

15. Andover M.S. Non-suicidal self-injury disorder in a community sample of adults. Psychiatry Res. 2014; 219: 305-310. DOI: 10.1016/j.psychres.2014.06.001

16. Klonsky E.D. Non-suicidal self-injury in United States adults: prevalence, sociodemographics, topography and functions. Psychol. Med. 2011; 41: 1981-1986. DOI: 10.1017/S0033291710002497

17. Word Preventing suicide: A global imperative Geneva, Word Health Organization. 2014. Available at http://www.who.int/mental_health/suicide-prevention/

18. Casey B.J., Jones R.M., Hare T.A. The adolescent brain. Ann. N. Y. Acad. Sci. 2008; 1124: 111-126.

19. Harter S., Stocker C., Robinson N.S. The perceived directionality of the link between approval and selfworth: the liabilities of a looking glass self-orientation among young adolescents. J. Res. Adolesc. 1996; 6: 285-308.

20. Somerville L.H., Jones R.M., Ruberry E.J., Dyke J.P., Glover G., Casey B.J. The medial prefrontal cortex and the emergence of self-conscious emotion in adolescence. Psychol. Sci. 2013; 24 (8): $1554-1562$.

21. Stroud L.R., Foster E., Papandonatos G.D., Handwerger K., Granger D.A. et al. Stress response and the adolescent transition: performance versus peer rejection stressors. Dev. Psychopathol. 2009; 21 (1): 47-68.

22. Whitlock J., Eckenrode J., Silverman D. Self-injurious behaviors in a college population. Pediatrics. 2006; 117: 1939-1948. DOI: 10.1542/peds.2005-2543 
23. Quinn P., Surgenor P., McGilloway S. An exploratory servicebased study of Deliberate Self-Harm (DSH) in Ireland: 'A hidden population'? Ir Med J. 2017 May 10; 110 (5): 561.

24. Gratz K.L. Risk factors for deliberate self-harm among female college students: the role and interaction of childhood maltreatment, emotional in expressivity, and affect intensity/reactivity. Am. J. Orthopsychiatry. 2006; 76: 238-250. DOI: 10.1037/00029432.76.2.238

25. Давидовский С.В. Особенности суицидального поведения среди жителей г. Минска. Здравоохранение. 2016; 3: 72-77. [Davidouski S.V. Features of suicidal behavior among Minsk inhabitants. Health. 2016; 3: 72-77.] (In Russ)

26. Bolognini M., Plancherel B., Laget J., Stephan P., Halfon O. Adolescents' self-mutilation - relationship with dependent behaviour. Swiss J. Psychol. 2003; 62: 241-249. DOI: 10.1024/14210185.62.4.241

27. Darche M.A. Psychological factors differentiating self-mutilating and non-self-mutilating adolescent inpatient females. Psychiatr. Hosp. 1990; 21: 31-35.

28. Klonsky E.D., Oltmanns T.F., Turkheimer E. Deliberate selfharm in a nonclinical population: prevalence and psychological correlates. Am. J. Psychiatry. 2003; 160: 1501-1508. DOI: 10.1176/appi.ajp.160.8.1501

29. Iannaccone M., Cella S., Manzi S., Visconti L., Manzi F., Cotrufo P. My body and me: self-injurious behaviors and body modifications in eating disorders - preliminary results. Eat. Disord. 2013; 21: 130-139. DOI: 10.1080/10640266.2013.761087

30. Graff H., Mallin R. The syndrome of the wrist cutter. Am. J. Psychiatry. 1967; 124: 74-80. DOI: 10.1176/ajp.124.1.36

31. Pao P. The syndrome of delicate self-cutting. Br. J. Med. Psychol. 1969; 42: 213-221. DOI: 10.1111/j.2044-8341.1969.tb02071.x

32. Rosenthal R., Rinzler C., Wallsch R., Klausner E. Wrist-cutting syndrome: the meaning of a gesture. Am. J. Psychiatry. 1972; 128: 1363-1368. DOI: 10.1176/ajp.128.11.1363

33. Kahan J., Pattison E.M. Proposal for a distinctive diagnosis: the deliberate self-harm syndrome (DSH). Suicide Life Threat. Behav. 1984; 14: 17-35. DOI: 10.1111/j.1943-278X.1984.tb00334.x

34. Favazza A.R., Rosenthal R.J. Varieties of pathological selfmutilation. Behav. Neurol. 1990; 3: 77-85. DOI: 10.3233/BEN1990-3202

35. Muehlenkamp J.J. Self-injurious behavior as a separate clinical syndrome. Am. J. Orthopsychiatry. 2005; 75: 324-333. DOI: 10.1037/0002-9432.75.2.324

36. Wilkinson P., Goodyer I. Non-suicidal self-injury. Eur. Child Adolesc. Psychiatry. 2011; 20: 103-108. DOI: 10.1007/s00787010-0156-y

37. Shaffer D., Jacobson C. Proposal to the DSM-V childhood disorder and mood disorder work groups to include non-suicidal selfinjury (NSSI) as a DSM-V disorder. Washington, DC: American Psychiatric Association, 2009.

38. Regier D.A., Narrow W.E., Clarke D.E., Kraemer H.C., Kuramoto S.J., Kuhl E.A. et al DSM-5 field trials in the United States and Canada, part II: test-retest reliability of selected categorical diagnoses. Am. J. Psychiatry. 2013; 170: 59-70. DOI: 10.1176/appi.ajp.2012.12070999

39. In-Albon T., Ruf C., Schmid M. Proposed diagnostic criteria for the DSM-5 of nonsuicidal self-injury in female adolescents: diagnostic and clinical correlates. Psychiatry J. 2013; 13: 159-208. DOI: $10.1155 / 2013 / 159208$

40. Turner B.J., Dixon-Gordon K.L., Austin S.B., Rodriguez M.A., Rosenthal M.Z., Chapman A.L. Non-suicidal self-injury with and without borderline personality disorder: differences in self-injury and diagnostic comorbidity. Psychiatry Res. 2015; 230: 28-35. DOI: 10.1016/j.psychres.2015.07.058

41. Selby E.A., Bender T.W., Gordon K.H., Nock M.K., Joiner T.E. Non-suicidal selfinjury (NSSI) disorder: a preliminary study. Personal. Disord. 2012; 3; 167-175. DOI: 10.1037/a0024405

42. Glenn C.R., Klonsky E.D. Nonsuicidal self-injury disorder: an empirical investigation in adolescent psychiatric patients. J. Clin. Child Adolesc. Psychol. 2013; 42: 496-507. DOI: 10.1080/15374416.2013.794699

43. Washburn J.J., Potthoff L.M., Juzwi K. R., Styer D.M. Assessing DSM-5 nonsuicidal self-injury disorder in a clinical sample. Psychol. Assess. 2015; 27: 31-41. DOI: 10.1037/pas0000021

44. Zetterqvist M., Lundh L.G., Dahlström Ö., Svedin C.G. Prevalence and function of non-suicidal self-injury (NSSI) in a com- munity sample of adolescents, using suggested DSM-5 criteria for a potential NSSI disorder. J. Abnorm. Child Psychol. 2013; 41: 759-773. DOI: 10.1007/s10802-013-9712-5

45. Gratz K.L., Dixon-Gordon K.L., Chapman A.L., Tull M.T. Diagnosis and characterization of DSM-5 non-suicidal self-injury disorder using the clinician administered non-suicidal self-injury disorder index. Assessment. 2015; 22: 527-539. DOI: $10.1177 / 1073191114565878$

46. Kaess M., Parzer P., Mattern M., Plener P.L., Bifulco A., Resch F., et al. Adverse childhood experiences and their impact on frequency, severity, and the individual function of nonsuicidal selfinjury in youth. Psychiatry Res. 2013; 206: 265-272. DOI: 10.1016/j.psychres.2012.10.012

47. Медико-социальные аспекты суицидального поведения подростков и молодежи / С.А. Игумнов, А.П. Гелда, Е.В. Гуткевич, Е.Д. Счастный / род научной редакцией академика РАН Н.А. Бохана. Москва, Минск, Томск. Издательство ООО Интегральный переплет», 2020. 178 c. [Medico-social aspects of suicidal behavior in adolescence and youth / S.A. Igumnov, A.P. Gelda, E.V. Gutkevich, E.D. Schastnyy / scientific editor academician of RAS N.A. Bokhan. Moscow, Minsk, Tomsk: Tomsk Center for Scientific and Technical Information, 2020. 178 p.] (In Russ)

48. Moran P., Coffey C., Romaniuk H., Olsson C., Borschmann R., Carlin J.B., Patton G.C. The natural history of self-harm from adolescence to young adulthood: A population based cohort study. The Lancet. 2011; 379: 236-243.

49. Nock M.K., Prinstein M.J. A functional approach to the assessment of self-mutilative behavior. J. Clin. Consult. Psychol 2004; 72: 885-890. DOI: 10.1037/0022-006X.72.5.885

50. Briere J., Gil E. Self-mutilation in clinical and general population samples: prevalence, correlates, and functions. Am. J. Orthopsychiatry. 1998; 68: 609-620. DOI: 10.1037/h0080369

51. Laye-Gindhu A., Schonert-Reichl K.A. Nonsuicidal self-harm among community adolescents: understanding the whats and whys of self-harm. J. Youth Adolesc. 2005; 34: 447-457. DOI: 10.1007/s10964-005-7262-z

52. Stanley B., Sher L., Wilson S., Ekman R., Huang Y., Mann J.J. Non-suicidal selfinjurious behaviour, endogenous opioids and monoamine neurotransmitters. Journal of Affective Disorders. 2010; 124: 134-140.

53. Plener P.L., Libal G., Keller F., Fegert J.M., Muehlenkamp J.J. An international comparison of non-suicidal self-injury (NSSI) and suicide attempts: Germany and the USA. Psychol. Med. 2009; 39: 1549-1558. DOI: 10.1017/S0033291708005114

54. Schmahl C., Bohus M., Esposito F., Treede R.D., Di Salle F., Greffrath W., Ludaescher P., Jochims A., Lieb K., Scheffler K., Hennig J., Seifritz E. Neural correlates of antinociception in borderline personality disorder. Archives of General Psychiatry. 2006; 63: 659-667.

55. Kraus A., Valerius G., Seifritz E., Ruf M., Bremner J.D., Bohus M., Schmahl C. Script-driven imagery of self-injurious behaviour in patients with borderline personality disorder: a pilot FMRI study. Acta Psychiatrica Scandinavica. 2010; 121: 41-51.

56. Janis I.B., Nock M.K. Are self-injurers impulsive? Results from two behavioral laboratory studies. Psychiatry Research. 2009; 169: 261-267.

57. Crowell S.E., Beauchaine T.P., McCauley E., Smith C.J., Stevens A.L., Sylvers P. Psychological, autonomic, and serotonergic correlates of parasuicide among adolescent girls. Dev. Psychopathol. 2005; 17 (4): 1105-1127.

58. Fanelli G., Serretti A. The influence of the serotonin transporter gene 5-HTTLPR polymorphism on suicidal behaviors: a metaanalysis. Prog. Neuropsychopharmacol. Biol. Psychiatry. 2018; 88: 375-387.

59. Давидовский С.В., Ибрагимова Ж.А., Гончарик А.В., Марчук С.И., Залесская И.С., Третьяк А.Н., Хвостова И.И., Данилова Л.И. Особенности генотипа лиц, совершивших парасуицид. Психиатрия, психотерапия и клиническая психология. 2019; 10 (3): 417-427. [Davidouski S., Ibragimova J., Goncharik A., Marchuk S., Zaleskaya I., Tretyk A.3., Hvostova I., Danilova L. Features of the genotype of individuals who have committed suicide attempts. Psychiatry, psychotherapy and clinical psychology. 2019; 10 (3): 417-427.] (In Russ)

60. Tiefenbacher S., Novak M.A., Lutz C.K., Meyer J.S. The physiology and neurochemistry of self-injurious behaviour: A nonhuman primate model. Frontiers in Bioscience. 2005; 10: 1-11. 
61. Kaess M., Hille M., Parzer P., Maser-Gluth C., Resch F., \& Brunner R. Alterations in the neuroendocrinological stress response to acute psychosocial stress in adolescents engaging in nonsuicidal self-njury. Psychoneuroendocrinology. 2012; 37 : 157-161.

62. Nixon M.K., Cloutier P.F., Aggarwal S. Affect regulation and addictive aspects of repetitive self- injury in hospitalized adolescents. Journal of the American Academy of Child and Adolescent Psychiatry. 2002; 41: 1333-1341.

63. Ludäscher P., Greffrath W., Schmahl C., Kleindienst N., Kraus A., Baumgärtner U., Magerl W., Treede R.D., Bohus M. A crosssectional investigation of discontinuation of self-injury and normalizing pain perception in patients with borderline personality disorder. Acta Psychiatrica Scandinavica. 2009; 120: 62-70.

64. Miller A.B., Prinstein M.J. Adolescent suicide as a failure of acute stress-response systems. Annual Reviera of Clinical Psychology. 2019; 2 : 12.

65. Давидовский С.В., Ибрагимова Ж.А., Гончарик А.В., Картун Л.В., Леонов Н.Н., Данилова Л.И., Кужаль В.В., Залесская И.С., Третьяк А.Н., Микицкий Ю.М. Классификационный метод прогнозирования суицидального риска. Вести Национальной академии наук Беларуси. Серия медицинских наук. 2020; 17 (2): 248-256. [Davydousky S.V., Ibragimova Zh. a.
Goncharik A.V., Kartun L.V., Leonov N.N., Danilova L.I., Kuzhal V.V., Zalesskaya I.S., Tretyak A.N., Mikitsky Yu.M. Classification method for predicting suicidal risk. News of the national Academy of Sciences of Belarus. Medical science series. 2020; 17 (2): 248-256.] (in Russ)

66. Dwivedi Y. The neurobiological basis of suicide / University Boca Raton (FL): CRC Press / Taylor \& Francis; 2012. 482 p.

67. van Heeringen $K$. The neuroscience of suicidal behavior. Hardcover / Cambridge University Press, 2018. 286 p.

68. Oquendo M.A., Baca-Garcia E. Suicidal behavior disorder as a diagnostic entity in the DSM-5 classification system: advantages outweigh limitations. World Psychiatry. 2014; 13: 128-130.

69. Galynker I., Yaseen Z.S., Cohen A., et al. Prediction of suicidal behavior in high risk psychiatric patients using an assessment of acute suicidal state: the suicide crisis inventory. Depress Anxiety. 2017; 34: 147-158.

70. Rogers M.L., Galynker I., Yaseen Z., et al. An overview and comparison of two proposed suicide-specific diagnoses: Acute Suicidal Affective Disturbance (ASAD) and Suicide Crisis Syndrome (SCS). Psychiatr Ann. 2017; 47: 416-420.

71. Joiner T.E., Simpson S., Megan J.D., Rogers L., Ian M.S., Stanley H., Galynker I.I. Law and Psychiatry. Journal of Psychiatric Practice. 2018; 24 (4): 124-129.

\section{MODERN CONCEPTIONS AND MANIFESTATION FEATURES OF SELF-HARMING BEHAVIOR}

\section{S.V. Davidouski ${ }^{1}$ S.A. Igumnov 2}

\author{
${ }^{1}$ Belarusian State Medical Academy for Postgraduate Education, Minsk, Belarus; \\ davidouski@yandex.by \\ 2 National Research Center for Addictions - branch of National medical research center of \\ psychiatry and narcology by name V.P. Serbsky, Moscow, Russia; sigumnov67@gmail.com
}

\section{Abstract:}

To date several biological risk factors have been identified as contributing to suicidal and self-harming behavior. The differences relate to changes in key neurotransmitter systems (serotonergic, polyamine stress response, glutamatergic and GABAergic systems), inflammatory response, astroglial dysfunction, neuronal plasticity factor, which confirms the need to differentiate people who do have a suicidal motive and who are prone to non-suicidal self-injurious behavior out of the total number of suicidal attempts. Non-suicidal self-injury (NSSI) is defined as repetitive, deliberate, direct injury to the body without suicidal intent that is not socially acceptable. The NSSI Integrated Theoretical Model for Development and Support suggests that this type of behavior functions as a method of regulating emotional experience and social interaction when a stressful event occurs. The NSSI is currently included in section 3 of the DSM-5 and is classified as a recommended condition for further study. In the American Diagnostic and Statistical Manual of Mental Disorders, Revision 4 (DSM-IV-TR) and ICD-10, NSSI is coded as a symptom of borderline personality disorder.

Keywords: suicidal behavior, self-injurious behavior, self-harm, suicidal intentions, borderline personality disorder, BPD

Вкмад авторов:

С.В. Давидовский: разработка дизайна исследования, обзор публикаций, написание и редактирование текста рукописи;

C.А. Игумнов: обзор публикаций по теме статьи, написание и редактирование текста рукописи

Authors' contributions:

S.V. Davidouski: developing the research design, reviewing of publications, article writing, article editing;

S.A. Igumnov: reviewing of publications of the article's theme; article writing, article editing.

Финансирование: Данное исследование не имело финансовой поддержки.

Financing: The study was performed without external funding.

Конфмикт интересов: Авторы заявцяют об отсутствии конфликта интересов.

Conflict of interest: The authors declare no conflict of interest.

Статья поступима / Article received: 02.08.2020. Принята к публикации / Accepted for publication: 01.11.2020.

Для цитирования: Давидовский С.В., Игумнов С.А. Современные концепции и особенности проявления самоповреждающего поведения. Суицидология. 2020; 11 (3): 33-43. doi.org/10.32878/suiciderus.20-11-03(40)-33-43

For citation: Davidouski S.V., Igumnov S.A. Modern conceptions and manifestation features of self-harming behavior. Suicidology. 2020; 11 (3): 33-43. (In Russ) doi.org/10.32878/suiciderus.20-11-03(40)-33-43 